\title{
iRGD-guided tamoxifen polymersomes inhibit estrogen receptor transcriptional activity and decrease the number of breast cancer cells with self-renewing capacity
}

María Inés Diaz Bessone', Lorena Simón-Gracia², Pablo Scodeller², María de los Angeles Ramirez', María Amparo Lago Huvelle ${ }^{1}$ Galo J. A. A. Soler-Illia ${ }^{1}$ and Marina Simian ${ }^{1 *}$ (1)

\begin{abstract}
Background: Tamoxifen (Tam) is the most frequent treatment for estrogen receptor (ER) positive breast cancer. We recently showed that fibronectin (FN) leads to Tam resistance and selection of breast cancer stem cells. With the aim of developing a nanoformulation that would simultaneously tackle ER and FN/ $\beta 1$ integrin interactions, we designed polyethylene glycol-polycaprolactone polymersomes polymersomes (PS) that carry Tam and are functionalized with the tumor-penetrating iRGD peptide (iRGD-PS-Tam).

Results: Polyethylene glycol-polycaprolactone PS were assembled and loaded with Tam using the hydration film method. The loading of encapsulated Tam, measured by UPLC, was $2.4 \pm 0.5 \mathrm{~mol}$ Tam/mol polymer. Physicochemical characterization of the PS demonstrated that iRGD functionalization had no effect on morphology, and a minimal effect on the PS size and polydispersity (176 nm and Pdi 0.37 for iRGD-TAM-PS and $171 \mathrm{~nm}$ and Pdi 0.36 for TAM-PS). iRGD-PS-Tam were taken up by ER+ breast carcinoma cells in 2D-culture and exhibited increased penetration of 3D-spheroids. Treatment with iRGD-PS-Tam inhibited proliferation and sensitized cells cultured on FN to Tam. Mechanistically, treatment with iRGD-PS-Tam resulted in inhibition ER transcriptional activity as evaluated by a luciferase reporter assay. IRGD-PS-Tam reduced the number of cells with self-renewing capacity, a characteristic of breast cancer stem cells. In vivo, systemic iRGD-PS-Tam showed selective accumulation at the tumor site.
\end{abstract}

Conclusions: Our study suggests iRGD-guided delivery of PS-Tam as a potential novel therapeutic strategy for the management of breast tumors that express high levels of FN. Future studies in pre-clinical in vivo models are warranted.

Keywords: Breast cancer, Tamoxifen, Endocrine resistance, Fibronectin, iRGD-guided polymersomes, Self-renewing capacity

\section{Introduction}

Breast cancer affects one in eight women worldwide [1]. Seventy five percent of diagnosed breast cancers are estrogen receptor (ER) positive [2]. Tamoxifen (Tam), a selective ER modulator, is the main endocrine treatment

\footnotetext{
*Correspondence: marsimian@gmail.com

${ }^{1}$ Instituto de Nanosistemas, Universidad Nacional de San Martín, 25 de

Mayo 1021, San Martín, 1650 Buenos Aires, Argentina

Full list of author information is available at the end of the article
}

prescribed to breast cancer patients [3], and current guidelines recommend 10 years of treatment [4]. One third of patients receiving Tam will relapse within 15 years of their initial diagnosis. Tam resistance is traditionally associated with overexpression/activation of growth factor receptors such as HER2, or IGF-R1 [5]. However, only $20 \%$ of patients present alterations in these signaling pathways suggesting that other mechanisms are involved. We have demonstrated that binding of $\beta 1$ integrins to fibronectin (FN) confers tamoxifen 
resistance to otherwise sensitive breast cancer cells [6]. In clinical human breast cancer samples, high expression of extracellular matrix components (such as FN, collagen 1A1, tenascin-C), and their receptors (e.g. $\beta 1$ integrins) is associated with endocrine resistance $[7,8]$. Moreover, both in vitro and in vivo, Tam exposure leads to the selection of $\beta 1$-positive breast cancer cells with self-renewing capacity, a characteristic of breast cancer stem cells $[9,10]$. Additionally, we recently demonstrated that $\beta 1$-integrin co-localizes with ER $\alpha$ at the cell membrane and in endosomes in breast cancer cell lines and in human normal and neoplastic tissue samples [11]. In the presence of FN, $\beta 1$ prolongs ERo's half-life and strengthens its transcriptional activity [11]. We hypothesized that targeting of $\beta 1$ integrin/FN interaction in combination with ER blockade could be an effective strategy to avoid emergence of FN-induced Tam resistance and the selection of breast cancer stem cells-events associated with cancer recurrence.

Nanoparticles (NPs) have physicochemical and biological properties that are fundamentally different from those that characterize the individual components that make them up. The ability to carry different hydrophilic and hydrophobic imaging and therapeutic payloads, their cellular uptake by endocytosis, and possibility of engineering multiple functions into single nanocarrier system (multifunctionality) render NPs interesting for drug delivery and diagnosis. Compared to free drugs, NP-based agents can be engineered to have improved biodistribution, pharmacokinetics, and toxicological properties. Polymersomes (PS) are formed by the selfassembly of amphiphilic copolymers in aqueous solutions into nanoscale vesicles that can accommodate hydrophilic and hydrophobic drugs at high concentrations [1214] and be labeled with different tracers: optical probes, MRI, and PET imaging agents [15]. PS exhibit an intrinsic tumor tropism that can be further enhanced by functionalization with affinity ligands for precision-guided delivery to solid malignancies $[16,17]$. Among them, the iRGD peptide (amino acid sequence: CRGDKGPDC) belongs to a new class of targeting ligands, tumor-penetrating peptides, that home to tumors and are actively transported into the extravascular tumor parenchyma [18]. iRGD contains an $\alpha v$-integrin-binding motif and an RGDK cryptic CendR motif that upon proteolytic activation mediates binding to neuropilin-1 (NRP-1) that is overexpressed and correlates with increased aggressiveness in several solid tumor types, including breast cancer $[18,19]$. When conjugated to therapeutic PS (and to other types of NPs), iRGD improves their tumor homing, penetration, and antitumor efficacy $[18,20,21]$. Moreover, iRGD has been shown to potentiate the effect of several drugs when co-administered with them [22] and is currently clinically developed for combination therapy of pancreatic cancer with gemcitabine and albumin-paclitaxel NPs (ClinicalTrials.gov identifier: NCT03517176).

At the cellular level, iRGD was previously shown to dramatically collapse cellular protrusions on FN-coated surfaces through a neuropilin-1 (NRP-1)-mediated negative regulation of FN-binding $\beta 1$-integrins [23]. This effect appeared to be specific for FN, as attachment of the cells to collagen I, mainly recognized by $\alpha 1 \beta 1$ and $\alpha 2 \beta 1$ integrins, was not inhibited by iRGD [23]. We hypothesized that the application of iRGD-functionalized Tam-loaded PS could be a rational strategy to reduce the selection of breast cancer stem cells by Tam and counteract the induction of endocrine resistance by FN.

Here we investigated the impact of iRGD-functionalized Tam-loaded PS on cultured human ER+ breast cancer cells and found that they resensitize cells to Tam when these are cultured in the presence of FN. Moreover, enrichment of breast cancer cells with self-renewing capacity induced by Tam is inhibited in the presence of iRGD. iRGD-functionalized Tam-loaded PS effectively inhibited ER's transcriptional activity as determined by a transcription reporter assay. Finally, we demonstrate that targeted PS home to breast cancer xenograft lesions in mice, suggesting potential therapeutic applications for in vivo modulation of ER-dependent cancers.

\section{Results}

\section{Assembly and characterization of Tam-loaded PS}

The PS were assembled and loaded with Tam using the hydration film method [24]. The loading of encapsulated Tam, measured by UPLC, was $2.4 \pm 0.5 \mathrm{~mol} \mathrm{Tam} / \mathrm{mol}$ polymer. iRGD PS labelling was determined by fluorescence. A calibration curve was performed with different concentrations of free iRGD, and iRGD concentration $(0.026 \pm 0.0025 \mathrm{mg} / \mathrm{mL})$ was obtained by linear regression (Additional file 1: Figure S1). TEM analysis demonstrated that iRGD functionalization had no effect on PS morphology (Fig. 1a) and confirmed the vesicular structure of the PS membrane (Fig. 1b, arrows). DLS analysis demonstrated that iRGD functionalization had a minimal effect on the PS size and polydispersity $(176 \mathrm{~nm}$ and Pdi 0.37 for iRGD-TAM-PS and $171 \mathrm{~nm}$ and Pdi 0.36 for TAM-PS; Fig. 1c).

\section{iRGD-functionalization increases uptake of Tam-loaded PS in cultured breast cancer cells}

We used MCF7 [25] and T47D [26] human breast cancer cell lines that are ER positive, sensitive to Tam and express NRP-1 [27] to study the interactions of FAMlabeled iRGD-guided and control PS with the cultured breast cancer cells. In 2D culture, functionalization of FAM-PS-Tam with iRGD resulted in a significant 

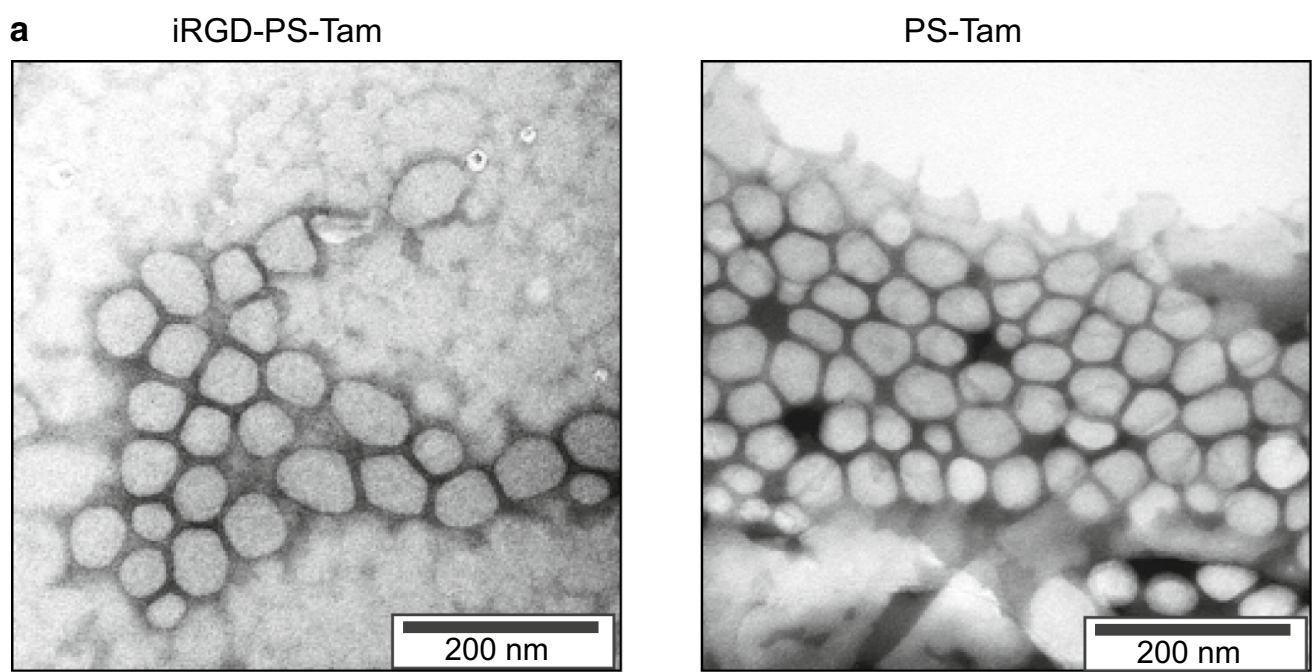

b
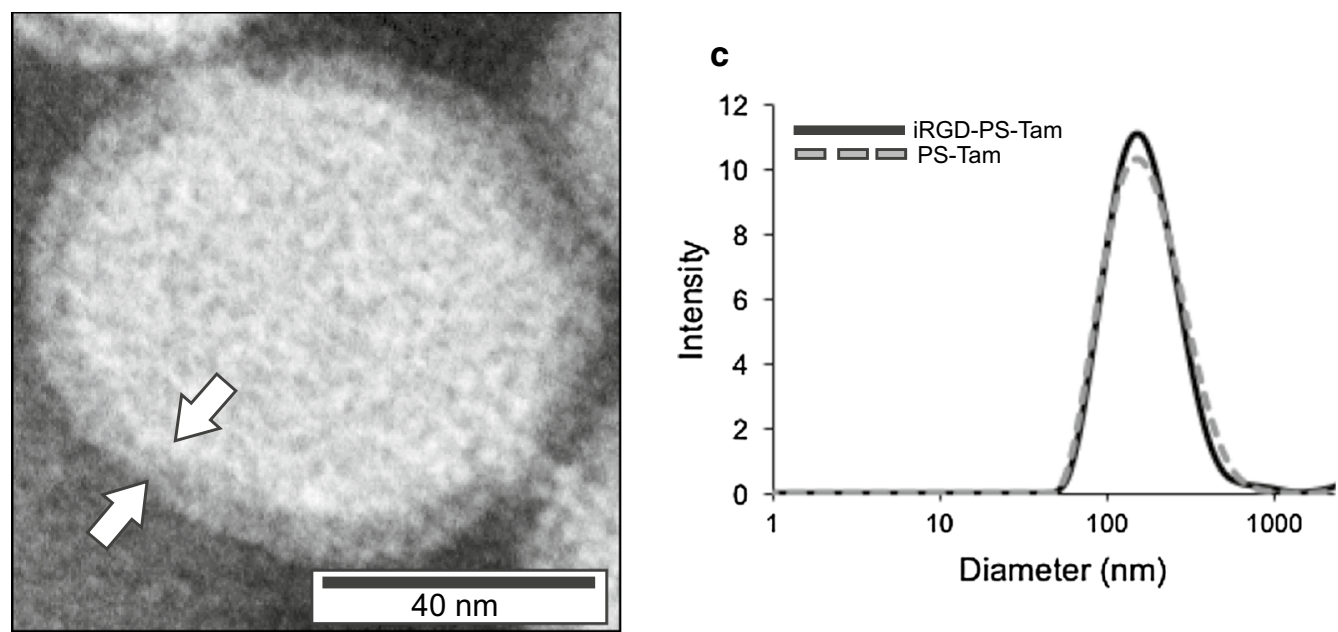

Fig. 1 Characterization of Tam-loaded PS. a TEM images of Tam-loaded iRGD-functionalized and untargeted PS. b TEM image of Tam-loaded PS showing the vesicle membrane (white arrows). c Size distribution measured by DLS of the iRGD-PS-Tam and PS-Tam

increase in the uptake of the PS in both cell lines, as determined by confocal microscopy (Fig. 2a) and quantification of the fluorescence intensity per cell (Fig. 2c).

Compared to 2D culture, cells in 3D culture represent increased physiological relevance [28]. As previously described, MCF-7 and T47D cells produce mass-like spheroids that are characterized by disorganized nuclei and robust cell-cell adhesion [29]. MCF-7 spheroids were more irregular and less compact than those generated by T47D cells. This may be explained by the higher levels of E-cadherin expressed by T47D cells in comparison to MCF7 cells [30]. After developing for 7 days, spheroids were treated with iRGD-FAM-PS-Tam or FAM-PS-Tam at $0.5 \mathrm{mg} / \mathrm{mL}$ for $24 \mathrm{~h}$. Irrespective of the morphology, FAM-labeled iRGD-PS-Tam were found distributed across both MCF7 and T47D spheroids, including the central cores, where high levels of fluorescence were observed (Fig. 2b, d). The control, non-targeted particles showed lower binding and were located mostly on the surface of the spheroids. Thus, derivatizing PS with iRGD significantly contributed to the uptake of the vehicles both in 2D and 3D culture models and increased their penetration in the $3 \mathrm{D}$ cultures.

\section{iRGD-PS-Tam are cytotoxic on cultured breast cancer cells}

MCF7 and T47D cells are sensitive to anti-estrogens, and Tam encapsulation in nanovehicles can be used to increase its toxicity [31, 32]. Moreover, to date Tam has not been encapsulated in PS and additionally combined with iRGD. We next studied the effect of treatment with 


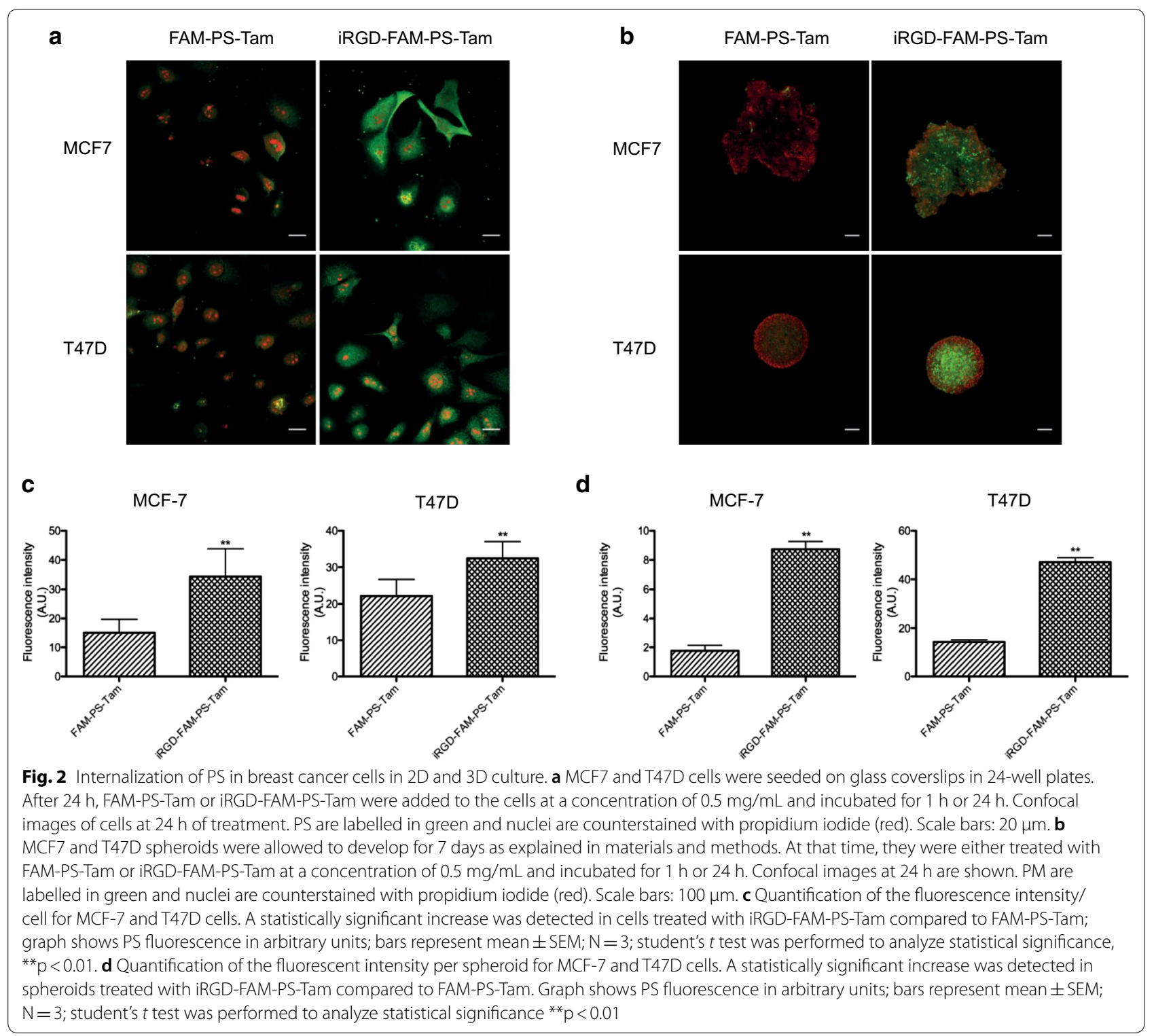

iRGD-PS-Tam and control compounds (at equivalent concentrations, as detailed in "Materials and methods") on MCF7 and T47D breast cancer cell lines cultured on BSA and FN matrices (Fig. 3). When MCF7 and T47D cells were cultured on BSA, iRGD-PS-Tam affected cell viability to a greater extent than free Tam (Fig. 3a, b). For both cell lines, encapsulation of Tam in PS did not increase the cytotoxic effect of free Tam (Fig. 3a, b). In the case of T47D cells the co-exposure to iRGD increased the cytotoxic effect of free Tam (Fig. 3b). When the cells were cultured on FN, free Tam did not have a significant effect on cell viability, as previously shown [6] (Fig. 3c, d). Interestingly, in MCF7 cells PS-Tam reverted this effect. Importantly, treatment of cells with iRGD-PS-Tam significantly decreased cell viability in both MCF7 and T47D cell lines (Fig. 3c, d). For MCF7 cells, co-administration of iRGD with either PS-Tam or free Tam also resensitized the cells to the anti-estrogen when cultured on FN. These results suggest that the encapsulation of Tam into PS partially increases the effectiveness of Tam treatment (at least in MCF7 cells), and that the incorporation of iRGD coating of the Tam-loaded PS increases the cytotoxic effect and reverts resistance induced by FN in both cell lines.

\section{iRGD-PS-Tam effectively inhibit ER transcriptional activity}

Tam is a selective ER modulator that competitively binds to ER and inhibits its transcriptional activity 
MCF7

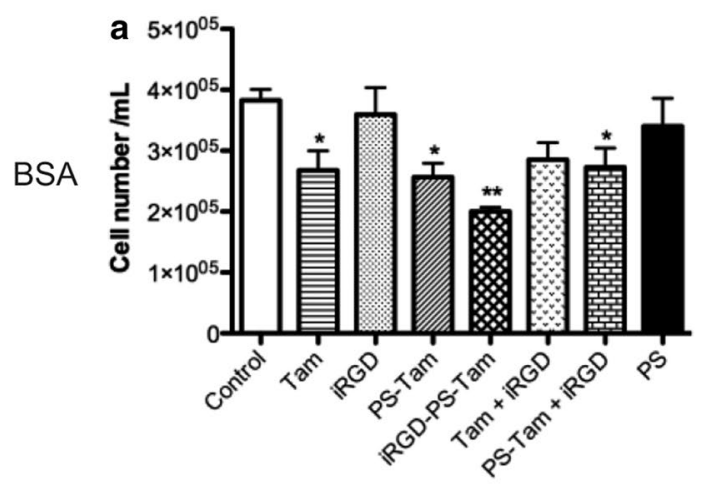

FN

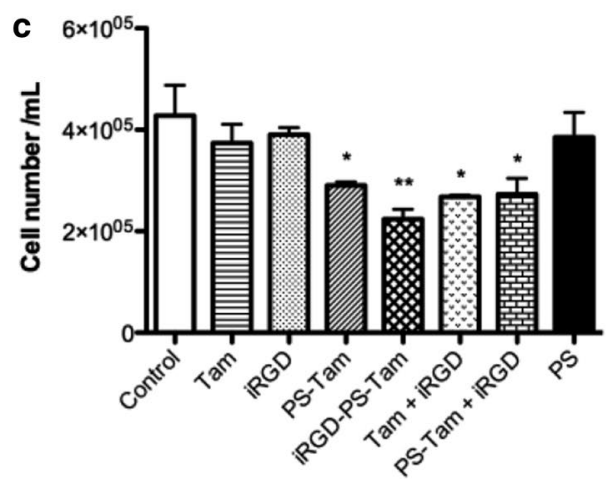

T47D
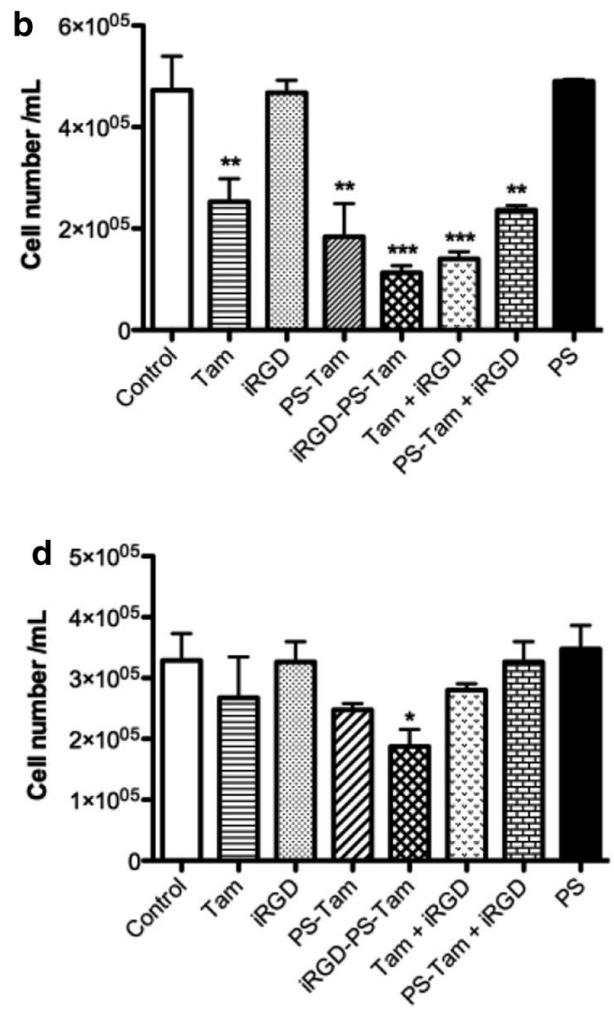

Fig. 3 Impact of iRGD-PS-Tam and control compounds on cell viability. Sixty thousand MCF7 or T47D cells were plated in 24 well plates coated with BSA or FN. Cells were treated for $96 \mathrm{~h}$ with Tam, iRGD, PS-Tam, iRGD-PS-Tam, Tam + iRGD, PS-Tam + iRGD or empty PS (PS). a, b Impact of the treatments on MCF7 and T47D cells plated on BSA. Bars represent mean \pm SEM; $N=3$; ${ }^{*} p<0.05 ;{ }^{* *} p<0.01$; one-way Anova followed by Sidak's multiple comparisons was used to compare groups, ${ }^{* *} p<0.001, N=3 . \mathbf{c}$, $\mathbf{d}$ show the effect of the treatments on MCF7 and T47D cells plated on $\mathrm{FN}$. Bars represent mean $\pm \mathrm{SEM} ; \mathrm{N}=3$; one-way Anova followed by Bonferroni-Sidak's multiple comparisons was used to compare the groups ${ }^{*} p<0.05 ;{ }^{* *} p<0.01 ;{ }^{* * *} p<0.001$

[3]. In Tam-sensitive cells this inhibition is associated with cell cycle arrest and apoptosis [3]. An inhibitory effect of Tam-loaded nanovehicles on transcriptional activity of ER has not been reported. To confirm that iRGD-PS-Tam can effectively release Tam to inhibit ER transcriptional activity, we carried out transcription reporter assays. MCF7 and T47D cells were transiently transfected with an estrogen-response-element (ERE)luciferase construct together with a tyrosine-kinase (TK)-Renilla plasmid and treated with estradiol, in the presence and absence of Tam and iRGD-PS-Tam. As expected, exposure to free Tam dramatically inhibited the estradiol-induced transcriptional activity of ER in both cell lines (Fig. 4a, b). A similar degree of inhibition was observed when cells were treated with estradiol in the presence of iRGD-PS-Tam. Interestingly, the inhibition of transcriptional activity with the iRGD-PS-Tam became apparent only at $20 \mathrm{~h}$, and not at $8 \mathrm{~h}$-time point usually used for experiments with free Tam (not shown). These results show that iRGD-PS-Tam exposure results in sustained intracellular release of Tam in its active form and is effective in inhibiting ER's transcriptional activity.

\section{Treatment with iRGD-PS-Tam reduces the number of cancer cells with self-renewing capacity}

Previously, we and others showed that Tam leads to the positive selection of cells with self-renewing capacity, a characteristic associated to breast cancer stem cells [9, $10,33]$. Moreover, these cells in breast cancer are characterized by the high expression of the $\beta 1$ integrin subunit (CD29) [34]. Thus, we explored whether the presence of iRGD on Tam-loaded PS would interfere with the enrichment in breast cancer cells with self-renewing capacity induced by Tam. 2D-cultured MCF7 and T47D cells were treated with free Tam, iRGD-PS-Tam, and iRGD 

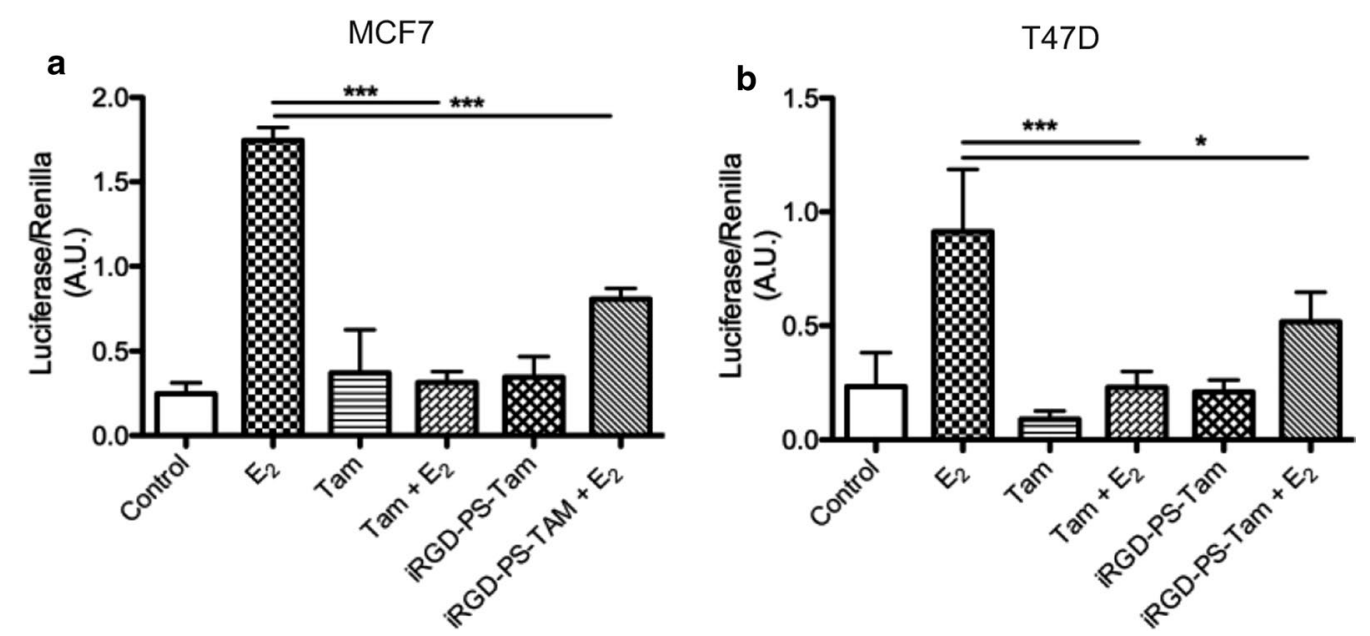

Fig. 4 iRGD-PS-Tam inhibits ER transcriptional activity. MCF7 (a) and T47D (b) cells were plated in 48 well plates and transiently transfected with PTK-ERE-Luc and pTK Renilla reporter constructs. The cells were subsequently treated for $24 \mathrm{~h}$ with estradiol $\left(\mathrm{E}_{2}\right)$, Tam, iRGD-PS-Tam, $\mathrm{E}_{2}+$ Tam and $\mathrm{E} 2+\mathrm{iRGD}-\mathrm{PS}$-Tam. Data are represented as mean $\pm \mathrm{SD}, \mathrm{N}=3$, one-way Anova followed by Bonferroni-Sidak's multiple comparisons was used to compare groups $* 0<0.05 ; * * * 00.001$

in combination with free Tam for $72 \mathrm{~h}$. Next, the cells were detached and re-plated on non-adherent cell culture plates in serum-free medium containing EGF and B27-conditions known to promote the development of breast cancer tumorspheres [35]. As shown in Fig. 5a, b, exposure to free Tam resulted in increased formation of tumorspheres. In contrast, for both MCF7 and T47D cell lines, the treatment with iRGD-PS-Tam reduced the number of cells capable of developing spheres. Interestingly, treatment of cells with iRGD in combination with free Tam had the same effect, suggesting that blocking $\beta 1$-integrins with this peptide may be sufficient to reduce breast cancer stem cells. These results have important clinical implications in the neoadjuvant setting where endocrine treatment has been shown to lead to an increase in breast cancer stem cells [36].

iRGD-PS-Tam home to mouse mammary xenograft lesions Next, MCF7 cells were injected in the right flank of athymic female Balb/c mice. Two weeks after tumor implantation, the mice were injected intravenously with iRGD-FAM-PS-Tam or iRGD + FAM-PS-Tam. Four hours later, the mice were sacrificed and tissues collected. Figure 6 shows immunofluorescence images of frozen tissue sections stained for CD31 in red and anti FAM in green. iRGD-FAM-PS-Tam accumulated preferentially in the tumor, as compared to other organs, showing colocalization with blood vessels positive for CD31. Nontargeted PS that were inoculated simultaneously with free iRGD showed very little accumulation in the tumor tissue. These results show that iRGD when attached to PS contributes to the homing of tamoxifen nanovehicles to the tumor tissue site (Fig. 6).

\section{iRGD-PS-Tam do not accumulate in normal mammary epithelial tissue adjacent to the tumor site}

Normal luminal breast epithelial cells have been shown express NRP-1 [37]. Thus, we investigated whether iRGDFAM-PS-Tam accumulated in normal tissue, adjacent to growing breast tumors. To do so we used the previously characterized M05 mouse mammary tumor that grows in immune-competent Balb/c mice [38]. In this case we chose a mouse model of breast cancer to avoid any differences in binding of iRGD between mouse and human cells in the same tissue. Mice were inoculated with M05 cells and tumors were allowed to grow for 4 weeks. At that stage, mice were treated with iRGD-FAM-PS-Tam for $4 \mathrm{~h}$, as explained in materials and methods. Tumors were harvested and quick-frozen together with the adjacent normal tissue. Frozen sections of the tumors and adjacent normal mammary gland were stained for NRP-1 and iRGD-FAM-PS-Tam. As shown in Fig. 7a, expression of NRP-1 was detected in normal mammary ducts and in the tumor cells. However, iRGD-FAM-PS-Tam was only detected associated to the tumor tissue (Fig. 7a, lower panel). Additionally, we tested whether normal mouse mammary cells would, in culture, uptake iRGD-FAMPS-Tam. To do so we used HC11 mouse mammary cells, that retain the ability to differentiate and produce milk proteins in culture [39]. First, we evaluated the levels of NRP-1, and found levels of expression similar to those of T47D cells (Fig. 7b). Next, cells were cultured in the presence of iRGD functionalized PS. Confocal microscopy 


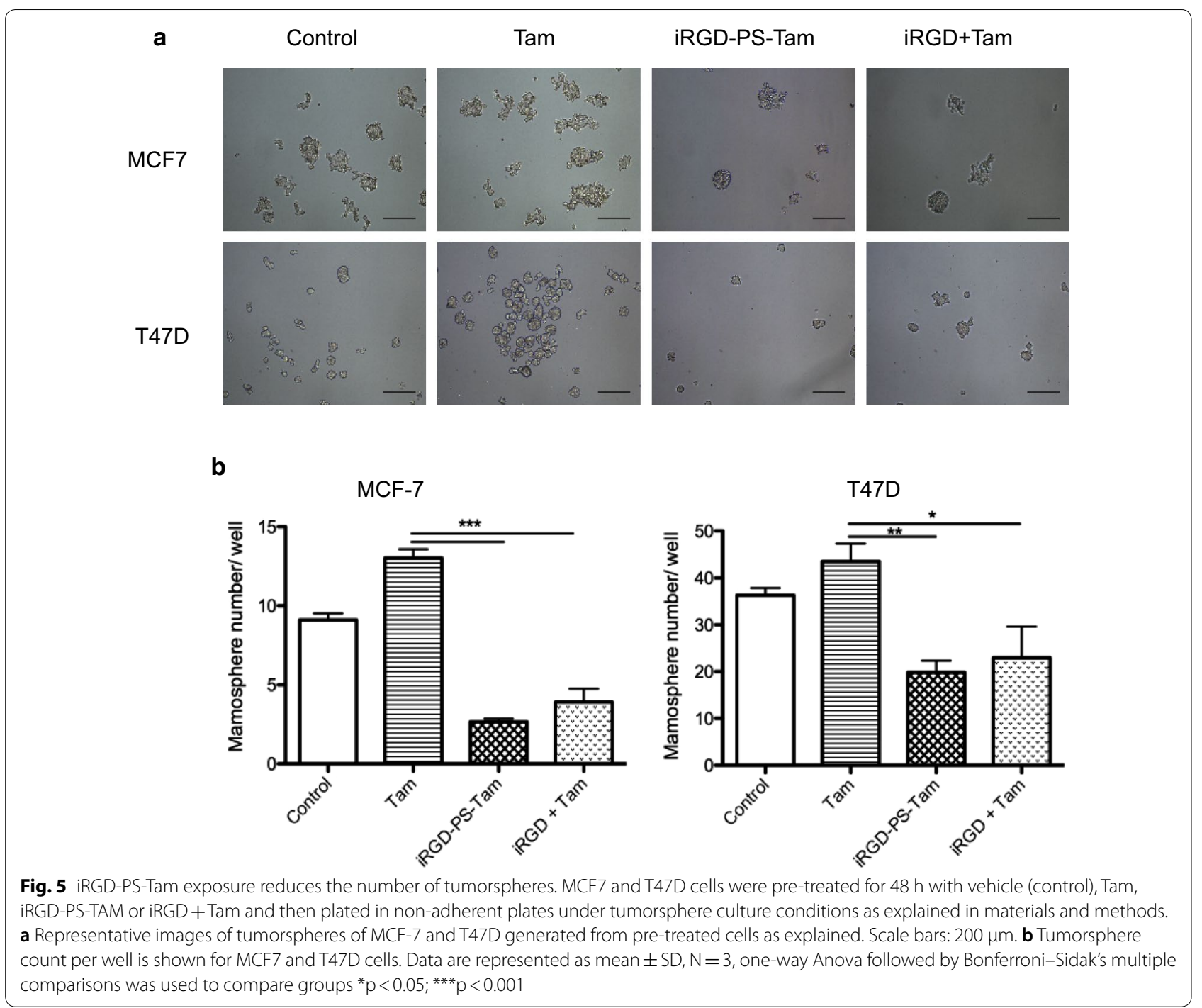

images and fluorescence quantification showed that the uptake in tumor and normal mammary cells was similar in culture (Fig. 7c). These results suggest that in vivo the fact that normal mammary cells do not uptake the iRGD-coated PS is related to their accumulation at the tumor site and not in the surrounding normal tissue. This is consistent with the fact that iRGD has been shown to bind preferentially to the tumor vasculature and then penetrate the tumor tissue [40].

\section{Discussion}

In this study, we developed and tested, on two human ER+ breast cancer cell lines, Tam-carrying PS functionalized with the tumor penetrating iRGD peptide. Our results show that Tam, delivered by these nanovehicles, is taken up by cells grown in 2 and 3D culture systems. Viability assays revealed that iRGD-PS-Tam inhibit cell proliferation and restore sensitivity to Tam when cells are grown on a FN-rich matrix. Moreover, inhibition of ER's transcriptional activity is achieved by treatment with iRGD-PS-Tam, indicating that Tam is actually released and is active within the cell nucleus. Importantly, treatment with iRGD-PS-Tam resulted in a reduction of breast cancer cells with self-renewing capacity-a functional characteristic of breast cancer stem cells. In addition, homing of systemic PS as evaluated in vivo, and selective accumulation at the tumor site was observed for iRGD-guided PS, specifically in breast cancer cells and not in the adjacent normal tissue. These results are summarized in Fig. 8.

Tam is the main therapy received by $75 \%$ of breast cancer patients worldwide [3]. It is administered daily as a 10-20 mg oral tablet. Multiple side-effects are associated to long-term administration of Tam. In particular, Tam 


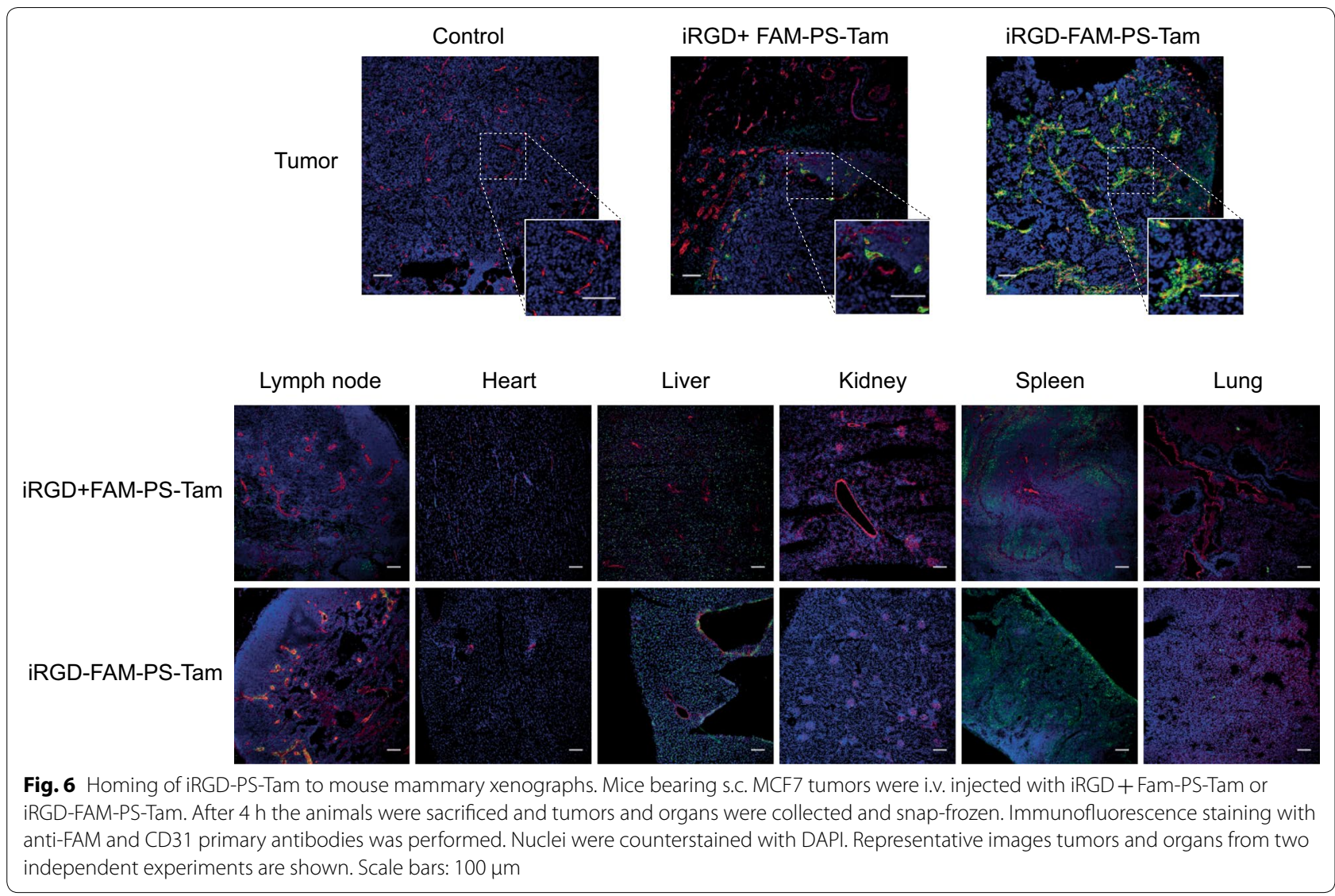

increases the risk of endometrial polyps and cancer, ovarian cysts, thromboembolism, thrombophlebitis, risk of stroke and ischemic attack [41]. Thus, it is of great clinical interest to develop Tam formulations that act specifically at the tumor site, without affecting other organs. Most efforts to vehiculize Tam so far have been carried out using non-targeted nanovehicles, and to our knowledge, very few biodistribution assays have been reported. For example, Martinez and collaborators developed alginate-cysteine/disulfide bond reduced albumin NPs that showed increased in vivo anti-tumor activity with increased drug concentration at the tumor site and undetectable levels of Tam in plasma [42]. They then functionalized these NPs with folate and found that this led to an increased accumulation of Tam in the tumor [43]. However, the accumulation of Tam in other organs remained the same and therapeutic response was not significantly improved as compared to the non-targeted NPs [43]. In another study, Tam was vehiculized in alpha-lipoic acidstearylamine conjugate-based solid lipid NPs [44]. In this case bioavailability was increased and hepatotoxicity was partially decreased. However, body weight loss was still observed in treated rats as compared to controls. Dhaundiyal and collaborators designed poly (lactic-co-glycolic acid) Tam NPs that showed increased bioavailability and a milder effect on body weight [44]. Our in vivo homing results show selective targeting of iRGD-PS-Tam to the tumor and very little accumulation in non-malignant tissues. Moreover, adjacent normal mammary tissue did not uptake the iRGD-labelled PS. In-depth therapy studies are required to test whether improved biodistribution of iRGD-targeted TAM-PS translates into improved efficacy/side effects profile and whether this could be a therapeutic alternative that leads to the elimination of metastatic dormant cells.

About half of patients will develop resistance either de novo, or after several years of treatment (acquired resistance) [5]. In this sense, the development of treatments that target more than one signaling pathway is of great interest for breast cancer patients. Accumulating evidence suggests that the tumor microenvironment is involved in the development of resistance to conventional treatments and that patient therapy should be determined according to the specific tumor microenvironment constitution. Integrin $\beta 1$ has been associated to treatment resistance in various tumor types and in the context of different treatment strategies, such as radiotherapy and chemotherapy [45-48]. We and others have shown 


\section{a}

b
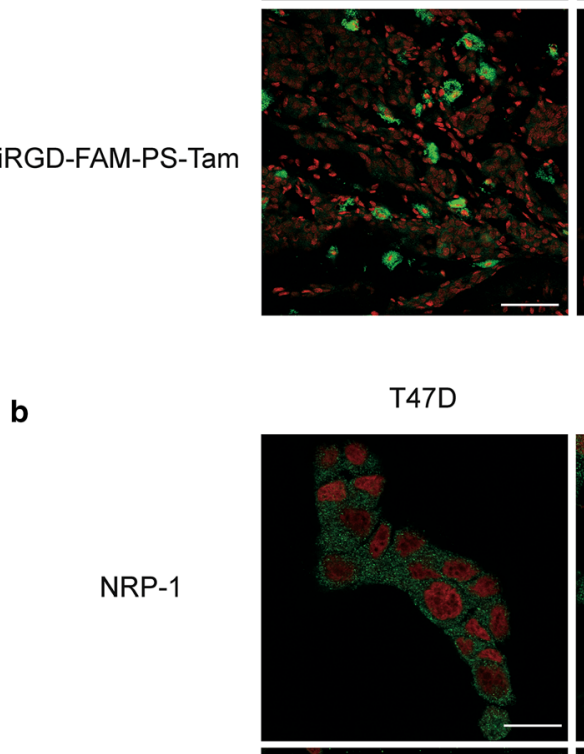

iRGD-FAM-PS-Tam

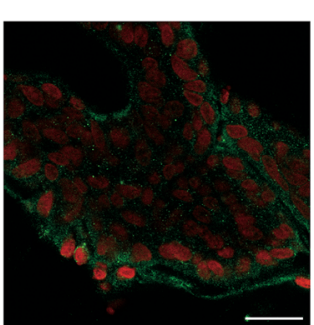

\section{Normal mammary ducts}
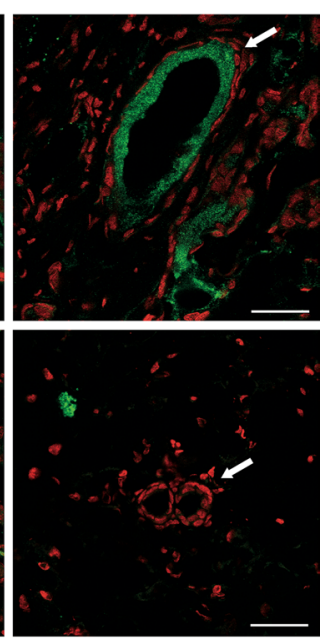

T47D
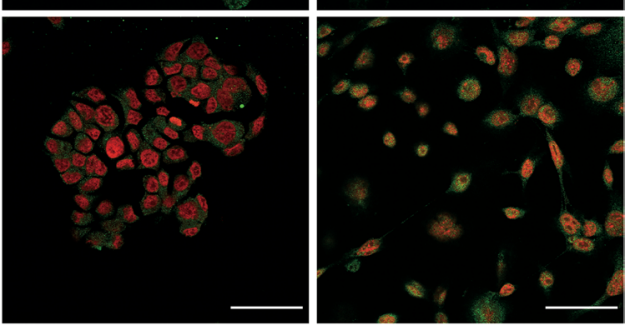

iRGD-FAM-PS-Tam

C

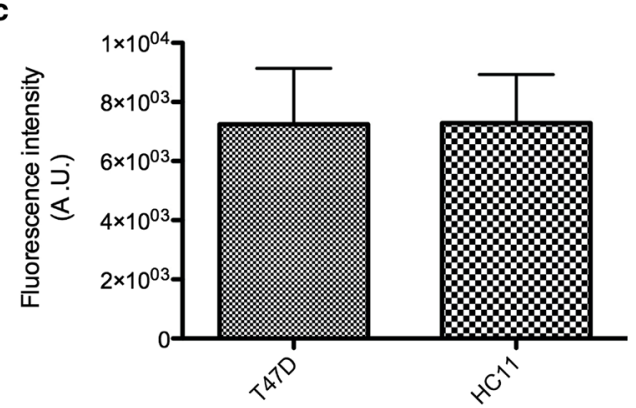

Fig. 7 iRGD-PS-Tam do not accumulate in normal mammary epithelial tissue adjacent to the tumor site. a Mice bearing s.c. M05 tumors were i.v. injected with iRGD-FAM-PS-Tam. After $4 \mathrm{~h}$ the animals were sacrificed and tumors and adjacent mammary gland were collected and snap-frozen. Immunofluorescence staining with anti-NRP-1 and FAM primary antibodies was performed. Nuclei were counterstained with RedDot. Representative images of tumors and normal mammary gland from two independent experiments are shown, where nuclei are shown in red and specific staining in green. Scale bars: $20 \mu \mathrm{m}$. b T47D and HC11 cells were seeded on glass coverslips in 24-well plates. After 24 h, iRGD-FAM-PS-Tam were added to the cells at a concentration of $0.5 \mathrm{mg} / \mathrm{mL}$ and incubated for $1 \mathrm{~h}$. PS are labelled in green and nuclei are counterstained with RedDot (red). Scale bars: $50 \mu \mathrm{m}$. Quantification of the fluorescence intensity/cell for T47D and HC11 cells. No statistically significant difference was detected between both cell lines; graph shows PS fluorescence in arbitrary units; bars represent mean $\pm S E M ; N=3$; student's $t$ test was performed to analyze statistical significance 


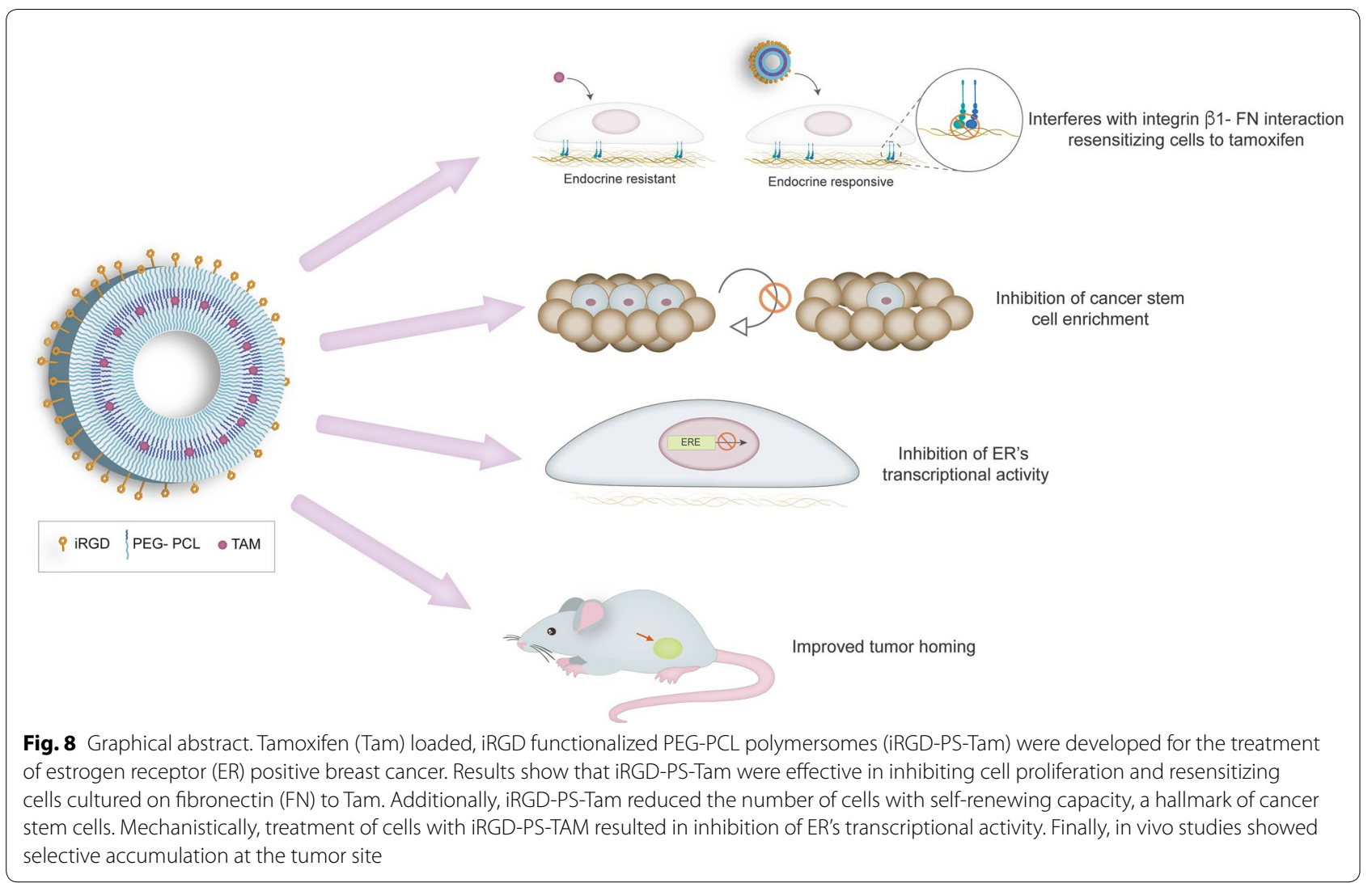

that signaling of FN through integrin $\beta 1$ is associated to endocrine resistance in breast cancer $[6,49]$. In this context, we hypothesized that blocking integrin $\beta 1$ together with ER would be a rational approach to improve the impact of Tam. Our results show that in 2D cultures on BSA the cytotoxic activity of iRGD-PS-Tam is similar to free Tam for both MCF7 and T47D cells. However, when seeded on FN, sensitivity to the anti-estrogen is recovered when the cells are treated with iRGD-PS-Tam. Of critical importance is the demonstration here that Tam contained within the iRGD-PS-Tam effectively interfered with ER's transcriptional activity, the key driver of tumor progression in ER+ breast cancers. To our knowledge this is the first demonstration of Tam delivered in a nanovehicle actually acting at the transcriptional level. A previous effort reported by Vural and collaborators carried out transcription reporter assays but were not able to demonstrate inhibition of ER's transcriptional activity by Tam vehiculized in $\beta$-cyclodextrin NPs [50]. Other authors have been able to show inhibition of ERs transcriptional activity using RU 58668, a selective ER downregulator, by encapsulating it in PEG-PLA nanospheres [51]. TAM and RU 58668 have different mechanisms of action [52] and thus delivery strategies may determine how they function at the molecular level. $\beta 1$ integrin is not only associated to metastasis and drug resistance, but additionally to stemness in the mammary gland [53, 54]. Thus, we asked the question of whether iRGD would interfere with the stem-cell enrichment effect that has been previously associated to Tam $[9,55]$. We found that, contrary to what we had previously observed in the presence of Tam, iRGD-PS-Tam reduced the number of cells with self-renewing capacity. Interestingly, adding iRGD to free Tam had the same effect. These results have important clinical implications for all types of breast cancer. First-line chemo and radiotherapy have been shown to lead to a selection of breast cancer stem cells that are more resistant to apoptosis [56-58]. A study using HepG2 liver cancer cells showed that iRGD increased the impact of salinomycin nanomicelles on the population of cancer cells with self-renewing capacity as evaluated by suspension sphere formation assays [59]. Further studies are needed to characterize the impact of iRGD on breast cancer stem cells and determined whether it may counteract their enrichment in the context of chemo and radiotherapy. However, our results together with those using HepG2 cells suggest iRGD may be especially useful in cancers that show a hierarchical relationship between cell populations within tumors [60, 61]. 
In summary, we show that iRGD directed Tam-loaded PS could be a potentially valuable tool to treat ER+ breast cancer. Further in vivo efficacy studies are underway, with a special emphasis in understanding the impact of this treatment, as compared to free Tam, on the population of cancer stem cells, and the establishment of metastatic foci in other organs.

\section{Methods}

\section{Reagents}

Tam (tamoxifen base) was purchased from SigmaAldrich, Germany. Phosphate-buffered saline (PBS) was purchased from Lonza, Belgium. Dulbecco's modified Eagle's medium (DMEM)/F12 was purchased from Sigma-Aldrich, Germany. MCF7 and T47D cell lines were purchased from ATCC. Athymic nude mice were purchased from HSD, and Balb/c mice were purchased from Charles River. Fluorescein (FAM) with a cysteine residue for PS coupling (FAM-Cys) was purchased from TAG Copenhagen A/S (Copenhagen, Denmark). iRGD peptide with an extra cysteine residue for PS coupling and labeled with fluorescein (FAM-Cys-iRGD; sequence:FAM-CysAhx-CRGDKGPDC; $A h x=$ aminohexanoic acid) was synthesized at Sanford Burnham Prebys Medical Discovery Institute. Maleimide-PEG(5 kDa)-b-PCL $(10 \mathrm{kDa})$ polymer (Mal-PEG-PCL) and PEG(5 kDa)-b-PCL(10 kDa) (PEG-PCL) were purchased from Advanced Polymer Materials Inc. (Montreal, Canada). Amicon filters were purchased from Merk Millipore, Germany.

\section{Preparation and characterization of PS}

To generate FAM-labeled PS (FAM-PS-Tam) or FAMlabeled iRGD-functionalized PS (iRGD-FAM-PS-Tam) with encapsulated Tam, $8 \mathrm{mg}$ of PEG-PCL polymer were mixed with $2 \mathrm{mg}$ of Mal-PEG-PCL polymer in acetone. To this solution, $50 \mu \mathrm{L}$ of a $20 \mathrm{mg} / \mathrm{mL}$ Tam solution in acetone was added and acetone was evaporated with a $\mathrm{N}_{2}$ flow to allow the formation of the polymer film. The films were hydrated with $1 \mathrm{~mL}$ of PBS and sonicated for $5 \mathrm{~min}$. A solution of $0.4 \mathrm{mg}$ of FAM-Cys or FAM-CysiRGD peptides in $100 \mu \mathrm{L}$ of PBS were added to the mix and sonicated for $15 \mathrm{~min}$.

For PS purification, the PS sample was centrifuged for $1 \mathrm{~min}$ at $500 \mathrm{~g}$ and the supernatant was purified using Amicon filters with a molecular weight cut-off of $100 \mathrm{KDa}$. The volume of the final PS solution was $1 \mathrm{~mL}$ at a concentration of $10 \mathrm{mg}$ polymer $/ \mathrm{mL}$. Dynamic Light Scattering (DLS) (Zetasizer Nano ZS, Malvern Instruments) was used to assess the PS polydispersity and average size. In addition, transmission electron microscopy (TEM) was used to visualize the PS surface topology, size, and structure [62, 63]. Briefly, PS in PBS were deposited onto copper grids at $1 \mathrm{mg} / \mathrm{mL}$, stained with $0.75 \%$ phosphotungstic acid ( $\mathrm{pH} 7)$, air-dried, and imaged by TEM (Tecnai 10, Philips, Netherlands). The amount of encapsulated Tam was quantified by ultraperformance liquid chromatography (UPLC) (Waters), using free Tam dissolved in $\mathrm{MeOH}$ to prepare the standard curve. Twenty five microliter of PS-Tam were mixed with $25 \mu \mathrm{L}$ of $\mathrm{MeOH}$ and $5 \mu \mathrm{L}$ of this mixture was run at $35{ }^{\circ} \mathrm{C}$ using water/acetonitrile with $0.1 \%$ formic acid as eluent and Acquity Ultraperformance UPLC BEH C18 $1.7 \mu \mathrm{M} 2.1 \times 50 \mathrm{~mm}$ column. FAM-iRGD peptide on PS was measured with an Infinite M200 microplate reader (Tecan, Männedorf, Switzerland) using 96 well polystyrene assay plates (Corning Inc., Corning, USA) and excitation and emission wavelengths of 494 and $518 \mathrm{~nm}$, respectively. To calculate the amount of FAM-iRGD peptides per mg of polymer, linear standards of the protein $(0-50 \mu \mathrm{g} / \mathrm{mL})$ were prepared to account for absorbance at 494 and $518 \mathrm{~nm}$.

\section{Cell culture}

The MCF7 [25], T47D [26] and HC11 [39] cell lines were routinely maintained in growth medium consisting of Dulbecco's modified Eagle's medium (DMEM/F12) supplemented with $10 \%$ fetal calf serum (FCS; GenSA, Buenos Aires, Argentina) and gentamicin in a humidified $5 \% \mathrm{CO}_{2} /$ air atmosphere. Serial passages were conducted by treatment of $80 \%$ confluent monolayers with $0.25 \%$ trypsin (Invitrogen, Carlsbad, CA) and 0.02\% EDTA in $\mathrm{Ca}^{2+}$-free and $\mathrm{Mg}^{2+}$-free phosphate buffered saline (PBS).

\section{Cell viability assay}

To evaluate the effects of FN, 24-well plates were coated by incubating with a solution of $2 \mu \mathrm{g} / \mathrm{mL}$ of FN or BSA for $1 \mathrm{~h}$ and washed with PBS. $6 \times 10^{4}$ MCF7 or T47D cells were seeded per well in complete growth medium. The next day, cells were washed twice with PBS and incubated in phenol red free DMEM/F12 with 1\% charcoalstripped FCS (chsFCS).

To compare the effects of Tam encapsulated in PS with treatment with free Tam, cells were treated with: EtOH as a control, free Tam, PS-Tam, iRGD-PS-Tam, free $i R G D$, free Tam + free iRGD, PS-Tam + iRGD, and empty PS (PS). In all cases, working concentration of Tam was $5 \times 10^{-6} \mathrm{M}$. The amount of iRGD in PS was calculated as mentioned before and the same amount was used as free iRGD. Cells were treated for $96 \mathrm{~h}$, and counted using a Neubauer Chamber.

\section{Tumor spheroid generation}

To generate spheroids, we adapted the hanging drop method [64]. Briefly, $1 \times 10^{4}$ cells were seeded on the cover of 48-well plates in $20 \mu \mathrm{L}$ drops. Covers were then 
inverted and incubated for $72 \mathrm{~h}$ until spheroids were fully formed, after which they were transferred into individual wells containing $500 \mu \mathrm{L}$ complete medium coated with $1.5 \%$ agarose. Spheroids were fed every other day by carefully aspirating $250 \mu \mathrm{L}$ of medium and replacing it with the same volume of fresh complete medium.

\section{Evaluation of cellular and spheroid uptake}

MCF7, T47D and HC11 cells $\left(5 \times 10^{5}\right.$ cells $)$ were seeded on glass coverslips in a 24-well plate. After $24 \mathrm{~h}$, PS were added to the cells at a concentration of $0.5 \mathrm{mg} / \mathrm{mL}$ and incubated for $1 \mathrm{~h}$ or $24 \mathrm{~h}$. The spheroids were grown for 7 days after which PS were added at the same concentration as cell uptake. The cells or spheroids were washed with PBS, fixed with $4 \%$ of paraformaldehyde in PBS, immuno-stained with Alexa 488-conjugated goat antirabbit IgG antibody (Abcam, USA), stained with propidium iodide, mounted and imaged with fluorescence confocal microscopy (Zeiss LSM 510). The images were processed and analyzed using the Image J software.

\section{Mammosphere assays}

Single cell suspensions derived from MCF7 or T47D cell lines were plated in 6-well low-attachment suspension culture plates (Greiner Bio-One, Koln, Germany) at a density of $1 \times 10^{4}$ viable cells $/ \mathrm{mL}$. Cells were grown in $2 \mathrm{~mL}$ serum-free media supplemented with B27 (Gemini Bioproducts, West Sacramento, CA) and $20 \mathrm{ng} / \mathrm{mL}$ epidermal growth factor as previously described [9]. Mammospheres were counted after 5-8 days in culture using a Nikon Eclipse TE2000-S inverted microscope.

\section{Luciferase reporter transcription assay}

MCF7 and T47D cells $\left(1 \times 10^{5}\right.$ cells $)$ were seeded in 48 well plate coated with BSA or FN $\left(2 \mu \mathrm{g} / \mathrm{cm}^{2}\right)$. The next day, cells were washed twice with PBS and then treated in phenol red free DMEM/F12 with $1 \%$ charcoal stripped FCS (chsFCS) for $24 \mathrm{~h}$. Next, cells were transfected with PTK-ERE-Luc and pTK Renilla vectors using Lipofectamine 2000 (Sigma-Aldrich, St. Louis, MO) according to manufacturer instructions. The weight ratio of Lipofectamine reagent to DNA was 3:1. The next day cells were treated with estradiol $\left(10^{-8} \mathrm{M}\right)$, free Tam $\left(10^{-6} \mathrm{M}\right)$, free Tam + estradiol, iRGD-PS-Tam $\left(10^{-6} \mathrm{M}\right)$ and iRGD-PS-Tam + estradiol using EtOH as control. After a $20 \mathrm{~h}$ incubation, cells were harvested with $30 \mu \mathrm{L}$ cell lysis buffer (Promega) and the firefly and renilla luciferase activities were determined using a dual luciferase assay kit (Promega) by measuring luminescence with a Wallac Micro-Beta scintillation counter (PerkinElmer Life Sciences). Firefly luciferase reporter activity was normalized to the renilla luciferase activity.

\section{In vivo biodistribution studies}

Animal care was in accordance with institutional guidelines. Tumor models were induced according to protocols approved by the Estonian Ministry of Agriculture, Committee of Animal Experimentation (permit \#48). Nude mice carrying $2.5 \mathrm{mg}$ silastic estrogen pellets were injected in the right flank with $5 \times 10^{6}$ MCF7 cells diluted in $100 \mu \mathrm{L}$ of a solution 1:1 of DMEM F12 and Matrigel (Corning Inc., Corning, USA). The MCF7 tumors were grown for 3 weeks and the FAM-labeled PS were injected IV ( $1 \mathrm{mg}$ of polymer in $100 \mu \mathrm{L}$ of PBS) and $4 \mathrm{~h}$ later the animals were perfused with $10 \mathrm{~mL}$ of PBS. Experiments with the M05 syngeneic mouse mammary tumors were approved by the "Angel $\mathrm{H}$. Roffo Institute" Animal Care Committee and carried in the Roffo Animal Facility, in Buenos Aires. M05 tumor cells were inoculated with a trocar in the right flank and allowed to grow for 4 weeks as previously published [38]. FAM-labeled PS were injected IV ( $1 \mathrm{mg}$ of polymer in $100 \mu \mathrm{L}$ of PBS) and $4 \mathrm{~h}$ later the animals were perfused with $10 \mathrm{~mL}$ of PBS. Tissues were snap-frozen in liquid nitrogen, and stored at $-80{ }^{\circ} \mathrm{C}$. The excised tumors and organs were cryosectioned at $10 \mu \mathrm{m}$, fixed with $4 \%$ of paraformaldehyde in PBS, and immunostained with rabbit anti-fluorescein (Life Technologies, USA), rat anti-mouse CD31 (BD Biosciences, USA), or rabbit anti-neuropilin-1 (Santa Cruz Biotechnology) as primary antibodies, and with Alexa 488-conjugated goat anti-rabbit IgG and Alexa 647-conjugated goat anti-rat IgG (Invitrogen, USA) as secondary antibodies. The nuclei of cells were stained with $10 \mu \mathrm{g} /$ mL DAPI or Red Dot Far Red Nuclear Stain (Biotium). Confocal images of the tissue sections were analyzed with image J software.

\section{Statistical analysis}

The statistical significance of differences between groups was calculated by applying one-way ANOVA, followed by Bonferroni-Sidak's multiple comparisons test. A value of $\mathrm{p}<0.05$ was considered significant.

\section{Supplementary information}

Supplementary information accompanies this paper at https://doi. org/10.1186/s12951-019-0553-4.

Additional file 1: Figure S1. iRGD PS labelling was determined by fluorescence. A calibration curve was performed with different concentrations of free $i R G D$, and $i R G D$ concentration was obtained by linear regression. Four independent experiments were performed with similar results; mean: $0.0265 \pm 0.0025 \mathrm{mg} / \mathrm{mL}$. Assays were run at $25^{\circ} \mathrm{C}$ and a pH of 7.4 .

\section{Acknowledgements}

We thank Dr. Tambet Teesalu for technical support. 


\section{Authors' contributions}

MS, LSG, PS and GJAASL designed research. LSG and MAR synthesized the PS IDB and MALH performed the in vitro experiments, LSG, IDB and PS carried out the in vivo homing experiments and analyzed the data. MS wrote the manuscript. All authors read and approved the final manuscript.

\section{Funding}

This work was supported by Grants from the Instituto Nacional del Cáncer, Ministerio de Salud de la Nación, Argentina and Préstamo BID-PICT 2016-0222, and donations from the Federico Deutsch Jack Yael Foundation and the Banchero Family to M.S., by the European Regional Development Fund Mobilitas Plus postdoctoral fellowship MOBJD11 (to L.S.G.). Authors also acknowledge ANPCYT (PICT 2014-3687 and 2015-3526) to GJAASI.

\section{Availability of data and materials}

The datasets used and/or analyzed during the current study are available from the corresponding author on reasonable request.

\section{Ethics approval and consent to participate}

Animal care was in accordance with institutional guidelines. All animal studies were approved by the Estonian Ministry of Agriculture, Committee of Animal Experimentation.

\section{Consent for publication}

Not applicable.

\section{Competing interests}

The authors declare that they have no competing interests.

\section{Author details}

${ }^{1}$ Instituto de Nanosistemas, Universidad Nacional de San Martín, 25 de Mayo 1021, San Martín, 1650 Buenos Aires, Argentina. ${ }^{2}$ Laboratory of Cancer Biology, Institute of Biomedicine and Translational Medicine, University of Tartu, Ravila 14b, 50411 Tartu, Estonia.

Received: 13 May 2019 Accepted: 25 November 2019

Published online: 07 December 2019

\section{References}

1. Ferlay J, Soerjomataram I, Dikshit R, Eser S, Mathers C, Rebelo M, et al. Cancer incidence and mortality worldwide: sources, methods and major patterns in GLOBOCAN 2012. Int J Cancer. 2015;136(5):E359-E386386.

2. Brufsky AM, Dickler MN. Estrogen receptor-positive breast cancer: exploiting signaling pathways implicated in endocrine resistance. Oncologist. 2018;23:528-39.

3. Jordan VC. Tamoxifen as the first targeted long-term adjuvant therapy for breast cancer. Endocr Relat Cancer. 2014;21(3):R235-R246246.

4. Davies C, Pan H, Godwin J, Gray R, Arriagada R, Raina V, et al. Long-term effects of continuing adjuvant tamoxifen to 10 years versus stopping at 5 years after diagnosis of oestrogen receptor-positive breast cancer: ATLAS, a randomised trial. Lancet. 2013:381(9869):805-16.

5. Osborne CK, Schiff R. Mechanisms of endocrine resistance in breast cancer. Annu Rev Med. 2011;62:233-47.

6. Pontiggia O, Sampayo R, Raffo D, Motter A, Xu R, Bissell MJ, et al. The tumor microenvironment modulates tamoxifen resistance in breast cancer: a role for soluble stromal factors and fibronectin through beta1 integrin. Breast Cancer Res Treat. 2012;133(2):459-71.

7. Helleman J, Jansen MP, Ruigrok-Ritstier K, van Staveren IL, Look MP, Meijer-van Gelder ME, et al. Association of an extracellular matrix gene cluster with breast cancer prognosis and endocrine therapy response. Clin Cancer Res. 2008;14(17):5555-64.

8. Bae YK, Kim A, Kim MK, Choi JE, Kang SH, Lee SJ. Fibronectin expression in carcinoma cells correlates with tumor aggressiveness and poor clinical outcome in patients with invasive breast cancer. Hum Pathol. 2013;44(10):2028-37.

9. Raffo D, Berardi DE, Pontiggia O, Todaro L, de Kier Joffe EB, Simian M. Tamoxifen selects for breast cancer cells with mammosphere forming capacity and increased growth rate. Breast Cancer Res Treat. 2013;142(3):537-48
10. Simoes BM, Vivanco MD. Cancer stem cells in the human mammary gland and regulation of their differentiation by estrogen. Future Oncol. 2011;7(8):995-1006.

11. Sampayo RG, Toscani AM, Rubashkin MG, Thi K, Masullo LA, Violi IL, et al. Fibronectin rescues estrogen receptor alpha from lysosomal degradation in breast cancer cells. J Cell Biol. 2018;217:2777-988.

12. Pegoraro C, Cecchin D, Gracia LS, Warren N, Madsen J, Armes SP, et al. Enhanced drug delivery to melanoma cells using PMPC-PDPA polymersomes. Cancer Lett. 2013;334(2):328-37.

13. Simon-Gracia L, Hunt H, Scodeller PD, Gaitzsch J, Braun GB, Willmore AM, et al. Paclitaxel-loaded polymersomes for enhanced intraperitoneal chemotherapy. Mol Cancer Ther. 2016;15(4):670-9.

14. Scodeller P, Simon-Gracia L, Kopanchuk S, Tobi A, Kilk K, Saalik P, et al. Precision targeting of tumor macrophages with a CD206 binding peptide. Sci Rep. 2017;7(1):14655.

15. Kunjachan S, Ehling J, Storm G, Kiessling F, Lammers T. Noninvasive imaging of nanomedicines and nanotheranostics: principles, progress, and prospects. Chem Rev. 2015;115(19):10907-37.

16. Discher BM, Won YY, Ege DS, Lee JC, Bates FS, Discher DE, et al. Polymersomes: tough vesicles made from diblock copolymers. Science. 1999;284(5417):1143-6.

17. Gaitzsch J, Huang X, Voit B. Engineering functional polymer capsules toward smart nanoreactors. Chem Rev. 2016;116(3):1053-93.

18. Sugahara KN, Teesalu T, Karmali PP, Kotamraju VR, Agemy L, Girard OM, et al. Tissue-penetrating delivery of compounds and nanoparticles into tumors. Cancer Cell. 2009;16(6):510-20.

19. Sharma S, Kotamraju VR, Molder T, Tobi A, Teesalu T, Ruoslahti E. Tumorpenetrating nanosystem strongly suppresses breast tumor growth. Nano Lett. 2017;17(3):1356-64.

20. Simon-Gracia L, Hunt H, Scodeller P, Gaitzsch J, Kotamraju VR, Sugahara $\mathrm{KN}$, et al. iRGD peptide conjugation potentiates intraperitoneal tumor delivery of paclitaxel with polymersomes. Biomaterials. 2016;104:247-57.

21. Wonder E, Simon-Gracia L, Scodeller P, Majzoub RN, Kotamraju VR, Ewert KK, et al. Competition of charge-mediated and specific binding by peptide-tagged cationic liposome-DNA nanoparticles in vitro and in vivo. Biomaterials. 2018;166:52-63.

22. Sugahara KN, Teesalu T, Karmali PP, Kotamraju VR, Agemy L, Greenwald $D R$, et al. Coadministration of a tumor-penetrating peptide enhances the efficacy of cancer drugs. Science. 2010;328(5981):1031-5

23. Sugahara KN, Braun GB, de Mendoza TH, Kotamraju VR, French RP, Lowy AM, et al. Tumor-penetrating iRGD peptide inhibits metastasis. Mol Cancer Ther. 2015:14(1):120-8.

24. Simon-Gracia L, Scodeller P, Fuentes SS, Vallejo VG, Rios X, San Sebastian $E$, et al. Application of polymersomes engineered to target $p 32$ protein for detection of small breast tumors in mice. Oncotarget. 2018;9(27):18682-977.

25. Soule HD, Vazguez J, Long A, Albert S, Brennan M. A human cell line from a pleural effusion derived from a breast carcinoma. J Natl Cancer Inst. 1973:51(5):1409-16.

26. Keydar I, Chen L, Karby S, Weiss FR, Delarea J, Radu M, et al. Establishment and characterization of a cell line of human breast carcinoma origin. Eur J Cancer. 1979;15(5):659-70.

27. Weigand M, Hantel $P$, Kreienberg R, Waltenberger J. Autocrine vascular endothelial growth factor signalling in breast cancer* Evidence from cell lines and primary breast cancer cultures in vitro. Angiogenesis. 2005;8(3):197-204.

28. Simian $M$, Bissell MJ. Organoids: a historical perspective of thinking in three dimensions. J Cell Biol. 2017;216(1):31-40.

29. Kenny PA, Lee GY, Myers CA, Neve RM, Semeiks JR, Spellman PT, et al. The morphologies of breast cancer cell lines in three-dimensional assays correlate with their profiles of gene expression. Mol Oncol. 2007;1(1):84-96.

30. Rizwan A, Cheng M, Bhujwalla ZM, Krishnamachary B, Jiang L, Glunde K. Breast cancer cell adhesome and degradome interact to drive metastasis. NPJ Breast Cancer. 2015:1:15017.

31. Mazumdar S, Italiya KS, Sharma S, Chitkara D, Mittal A. Effective cellular internalization, cell cycle arrest and improved pharmacokinetics of Tamoxifen by cholesterol based lipopolymeric nanoparticles. Int J Pharm. 2018;543(1-2):96-106.

32. Ravikumara NR, Bharadwaj M, Madhusudhan B. Tamoxifen citrate-loaded poly $(D, I)$ lactic acid nanoparticles: evaluation for their anticancer activity in vitro and in vivo. J Biomater Appl. 2016:31(5):755-72. 
33. Ao A, Morrison BJ, Wang H, Lopez JA, Reynolds BA, Lu J. Response of estrogen receptor-positive breast cancer tumorspheres to antiestrogen treatments. PLoS ONE. 2011;6(4):e18810.

34. Shackleton M, Vaillant F, Simpson KJ, Stingl J, Smyth GK, Asselin-Labat ML, et al. Generation of a functional mammary gland from a single stem cell. Nature. 2006;439(7072):84-8.

35. Dontu G, Abdallah WM, Foley JM, Jackson KW, Clarke MF, Kawamura MJ, et al. In vitro propagation and transcriptional profiling of human mammary stem/progenitor cells. Genes Dev. 2003;17(10):1253-70.

36. Sansone P, Storci G, Giovannini C, Pandolfi S, Pianetti S, Taffurelli M, et al. p66Shc/Notch-3 interplay controls self-renewal and hypoxia survival in human stem/progenitor cells of the mammary gland expanded in vitro as mammospheres. Stem Cells. 2007;25(3):807-15.

37. Wild JR, Staton CA, Chapple K, Corfe BM. Neuropilins: expression and roles in the epithelium. Int J Exp Pathol. 2012;93(2):81-103.

38. Simian M, Manzur T, Rodriguez V, de Kier Joffe EB, Klein S. A spontaneous estrogen dependent, tamoxifen sensitive mouse mammary tumor: a new model system to study hormone-responsiveness in immune competent mice. Breast Cancer Res Treat. 2009;113(1):1-8.

39. Ball RK, Friis RR, Schoenenberger CA, Doppler W, Groner B. Prolactin regulation of beta-casein gene expression and of a cytosolic 120-kd protein in a cloned mouse mammary epithelial cell line. Embo J. 1988;7(7):2089-95.

40. Teesalu T, Sugahara KN, Ruoslahti E. Tumor-penetrating peptides. Front. Oncol. 2013;3:216

41. Ellis AJ, Hendrick VM, Williams R, Komm BS. Selective estrogen receptor modulators in clinical practice: a safety overview. Expert Opin Drug Saf. 2015;14(6):921-34

42. Martinez A, Muniz E, Iglesias I, Teijon JM, Blanco MD. Enhanced preclinical efficacy of tamoxifen developed as alginate-cysteine/disulfide bond reduced albumin nanoparticles. Int J Pharm. 2012;436(1-2):574-81.

43. Martinez A, Muniz E, Teijon C, Iglesias I, Teijon JM, Blanco MD. Targeting tamoxifen to breast cancer xenograft tumours: preclinical efficacy of folate-attached nanoparticles based on alginate-cysteine/disulphidebond-reduced albumin. Pharm Res. 2014;31(5):1264-74.

44. Dhaundiyal A, Jena SK, Samal SK, Sonvane B, Chand M, Sangamwar AT. Alpha-lipoic acid-stearylamine conjugate-based solid lipid nanoparticles for tamoxifen delivery: formulation, optimization, in-vivo pharmacokinetic and hepatotoxicity study. J Pharm Pharmacol. 2016;68(12):1535-50.

45. Hu Z, Gao S, Gao J, Hou R, Liu C, Liu J, et al. Elevated levels of Lewis y and integrin alpha5beta1 correlate with chemotherapeutic drug resistance in epithelial ovarian carcinoma. Int J Mol Sci. 2012;13(12):15588-60000.

46. Eke I, Deuse Y, Hehlgans S, Gurtner K, Krause M, Baumann M, et al. beta(1) Integrin/FAK/cortactin signaling is essential for human head and neck cancer resistance to radiotherapy. J Clin Invest. 2012;122(4):1529-40.

47. Park CC, Zhang HJ, Yao ES, Park CJ, Bissell MJ. Beta1 integrin inhibition dramatically enhances radiotherapy efficacy in human breast cancer xenografts. Cancer Res. 2008;68(11):4398-405.

48. Hamidi H, Pietila M, Ivaska J. The complexity of integrins in cancer and new scopes for therapeutic targeting. Br J Cancer. 2016;115(9):1017-23.

49. Yao ES, Zhang H, Chen YY, Lee B, Chew K, Moore D, et al. Increased beta1 integrin is associated with decreased survival in invasive breast cancer. Cancer Res. 2007;67(2):659-64.

50. Vural I, Memisoglu-Bilensoy E, Renoir JM, Bochot A, Duchêne D, Hincal AA. Transcription efficiency of tamoxifen citrate-loaded $\beta$-cyclodextrin nanoparticles. J Drug Deliv Sci Technol. 2005;15(5):339-42.
51. Maillard S, Ameller T, Gauduchon J, Gougelet A, Gouilleux F, Legrand $P$, et al. Innovative drug delivery nanosystems improve the anti-tumor activity in vitro and in vivo of anti-estrogens in human breast cancer and multiple myeloma. J Steroid Biochem Mol Biol. 2005;94(1-3):111-21.

52. Traboulsi T, El Ezzy M, Gleason JL, Mader S. Antiestrogens: structure-activity relationships and use in breast cancer treatment. J Mol Endocrinol. 2017;58(1):R15-R31.

53. Seguin L, Desgrosellier JS, Weis SM, Cheresh DA. Integrins and cancer: regulators of cancer stemness, metastasis, and drug resistance. Trends Cell Biol. 2015;25(4):234-40.

54. Pontier SM, Muller WJ. Integrins in mammary-stem-cell biology and breast-cancer progression-a role in cancer stem cells? J Cell Sci. 2009;122(Pt 2):207-14.

55. Simoes BM, Piva M, Iriondo O, Comaills V, Lopez-Ruiz JA, Zabalza I, et al. Effects of estrogen on the proportion of stem cells in the breast. Breast Cancer Res Treat. 2011;129(1):23-35.

56. Chang CH, Zhang M, Rajapakshe K, Coarfa C, Edwards D, Huang S, et al. Mammary stem cells and tumor-initiating cells are more resistant to apoptosis and exhibit increased DNA repair activity in response to DNA damage. Stem Cell Rep. 2015;5(3):378-91.

57. Chen X, Liao R, Li D, Sun J. Induced cancer stem cells generated by radiochemotherapy and their therapeutic implications. Oncotarget. 2017;8(10):17301-12

58. Gong C, Yao H, Liu Q, Chen J, Shi J, Su F, et al. Markers of tumorinitiating cells predict chemoresistance in breast cancer. PLOS ONE. 2010;5(12):e15630.

59. Mao X, Liu J, Gong Z, Zhang H, Lu Y, Zou H, et al. iRGD-conjugated DSPEPEG2000 nanomicelles for targeted delivery of salinomycin for treatment of both liver cancer cells and cancer stem cells. Nanomedicine (Lond). 2015;10(17):2677-95.

60. Maley CC, Aktipis A, Graham TA, Sottoriva A, Boddy AM, Janiszewska M, et al. Classifying the evolutionary and ecological features of neoplasms. Nat Rev Cancer. 2017;17(10):605-19.

61. Campbell LL, Polyak K. Breast tumor heterogeneity: cancer stem cells or clonal evolution? Cell Cycle. 2007;6(19):2332-8.

62. LoPresti C, Massignani M, Fernyhough C, Blanazs A, Ryan AJ, Madsen J, et al. Controlling polymersome surface topology at the nanoscale by membrane confined polymer/polymer phase separation. ACS Nano. 2011;5(3):1775-844.

63. Ruiz-Perez L, Messager L, Gaitzsch J, Joseph A, Sutto L, Gervasio FL, et al. Molecular engineering of polymersome surface topology. Sci Adv. 2016:2(4):e1500948.

64. Del Duca D, Werbowetski T, Del Maestro RF. Spheroid preparation from hanging drops: characterization of a model of brain tumor invasion. J Neurooncol. 2004;67(3):295-303.

\section{Publisher's Note}

Springer Nature remains neutral with regard to jurisdictional claims in published maps and institutional affiliations.

Ready to submit your research? Choose BMC and benefit from

- fast, convenient online submission

- thorough peer review by experienced researchers in your field

- rapid publication on acceptance

- support for research data, including large and complex data types

- gold Open Access which fosters wider collaboration and increased citations

- maximum visibility for your research: over 100M website views per year

At BMC, research is always in progress.

Learn more biomedcentral.com/submissions 